\title{
A comparison between fuel cells and other alternatives for marine electric power generation
}

\author{
Yousri M. A. Welaya, M. Morsy El Gohary and Nader R. Ammar
}

Department of Naval Architecture \& Marine Engineering, Alexandria University, Egypt

\begin{abstract}
The world is facing a challenge in meeting its needs for energy. Global energy consumption in the last halfcentury has increased very rapidly and is expected to continue to grow over the next 50 years. However, it is expected to see significant differences between the last 50 years and the next. This paper aims at introducing a good solution to replace or work with conventional marine power plants. This includes the use of fuel cell power plant operated with hydrogen produced through water electrolysis or hydrogen produced from natural gas, gasoline, or diesel fuels through steam reforming processes to mitigate air pollution from ships.
\end{abstract}

KEY WORDS: Fuel cell; Marine electric power generation; Power balance mathematical modeling.

\section{NOMENCLATURE}

$A_{\text {active }}$

$C_{p}$

$C V_{\text {Fuel }}$

$\mathrm{CO}$

$\mathrm{CO}_{2}$

$D C$

$E_{o}$

$E M F$

F

FCPP

$H C$

$\Delta h_{f}$

$i_{c a l}$

$m_{\text {Air }}$

$m_{H 2}$

$m_{H 2 \text { consum }}$

$m_{O 2}$

$m_{\text {water }}$

$n_{\text {cell }}$

$N O_{x}$
Active area for fuel cell stack

Water specific heat at constant

Fuel calorific value

Carbon monoxide

Carbon dioxide

Direct current

Open circuit voltage or EMF

Electromotive force of fuel cell

Faraday's constant

Fuel cell power plant

Hydrocarbon emissions

Change in enthalpy

Calculated current

Required Air mass flow rate

Required hydrogen mass flow rate

Hydrogen mass flow rate reacted in

Required Oxygen mass flow rate

Fuel cell water produced mass flow

Number of cell per stack

Nitrogen oxides emissions
$P_{1}$

$P_{2}$

$P_{\text {env }}$

$P_{\text {in }}$

$P_{e l}$

$P_{\text {eld }}$

$P_{\text {heat }}$

$P_{\text {out }}$

Volt $\quad R$

Volt

Coulomb/

$U_{f}$

\section{$\mathrm{kJ} / \mathrm{kg}$}

Amber

$\mathrm{kg} / \mathrm{s}$

$\mathrm{kg} / \mathrm{s}$

$\mathrm{kg} / \mathrm{s}$

$\mathrm{kg} / \mathrm{s}$

$\mathrm{kg} / \mathrm{s}$

Corresponding author: Yousri Welaya

e-mail: y_welaya@hotmail.com
Fuel cell product pressure bar

Fuel cell reactant pressure bar

Power lost to the environment $\quad k W$

Fuel cell input power $\quad \mathrm{kW}$

Power produced by fuel cell stack Watt

Fuel cell output power density $\quad \mathrm{kW} / \mathrm{cm}^{2}$

Heating power $\quad k W$

Power in exit flow stream $\quad k W$

Universal gas constant J/mole.k

Stack temperature of fuel cell $\quad{ }^{\circ} \mathrm{K}$

Cooling water temperature ${ }^{\circ} \mathrm{C}$

Fuel utilisation coefficient

Cell voltage of fuel cell stack Volt

Fuel cell efficiency

$\%$

Stoichiometric ratio of air

\section{INTRODUCTION}

The need for renewable or green energy sources in addition to improving the efficiency of using current fossil fuels in the marine field, makes it important to replace or improve current fossil-fueled engines. Very low emissions and relatively high efficiencies have been found in marine power plants using fuel cells. Fuel cells can be operated with different fuels like using natural gas, gasoline, diesel, and hydrogen. Fuel cell emission levels will be accepted by the 
required international marine regulations addressed by the International Maritime Organization (IMO) and the International Convention for the Prevention of Pollution from Ships (MARPOL). In addition to that, fuel cell has a high fuel to electricity efficiency ranging between $40 \%$ and $60 \%$ (El-Gohary, 2007, 2008; Hordeski, 2008). However, the system efficiency (including reformers and auxiliary equipment) is lower.

\section{FUEL CELLS ON MERCHANT SHIPS}

Several types of fuel cell could be developed for surface ship applications. However, considerations here will be mainly restricted to those which are furthest advanced and can readily use diesel oil reformat as a fuel and air as an oxidant (Woud and Stapersma, 2003; El-Gohary et al. 2008). It cannot be expected that a fuel with a sulfur content above $0.2 \%$ of weight be used as fuel for fuel cells.

From the beginning of September 2008, the first commercial fuel cell-powered passenger ship is operating a regular service on the river Alster in Hamburg, Germany. Up to 100 passengers are able to enjoy each river excursion, without giving rise to any harmful emissions. The Zem Ship (Zero Emission Ship), based in the port of Hamburg, Germany, is running on a hybrid unit integrating two of Proton Motor's $48 \mathrm{~kW}$ fuel cell systems and a lead gel battery. It uses up to $50 \mathrm{~kg}$ of gaseous hydrogen stored in tanks on board, sufficient to provide fuel for around three days' use (Ritch, 2008).

The operation of pure hydrogen and air PEM fuel cells is, however, likely to be restricted to ships carrying hydrogen as a cargo. This is because the low volumetric energy density requires very sizeable fuel tanks and because additional safety precautions are also necessary. In Germany, the Association of Mussel Fishers decided in 1996 to equip the Mussel-Fishing fleet with the most environmentally friendly propulsion possible. One possible solution is the use of fuel cells instead of conventional diesel generators. As indicated by Sattler (Sattler, 2000), safety engineering aspects and components are being developed in cooperation with one of the members of the International Association of Classification Societies, namely, "Germanischer Lloyd".

\section{MARINE FUEL CELLS AND REGULATIONS}

The technology associated with the design, manufacture and operation of marine equipment is changing rapidly. The traditional manner in which regulatory requirements for marine electrical power supply systems have developed, based largely on incidents and failures, is no longer acceptable. Current international requirements for marine electrical power supply equipment and machinery such as engines, turbines and batteries have evolved over decades and their applicability to new technologies and operating regimes is now being questioned by organizations responsible for the regulation of safety and reliability of ships. The first Rules for using fuel cells was from GL in 2003 in addition to the International Gas Fuel (IGF) Code development. In addition, DNV (Det Norske Veritas), BV (Bureau Veritas) and other classification societies are working hard to develop Rules for using fuel cell in the marine field.

The main hurdles in the assessment of fuel cells as a marine electrical power generator for classification purposes may be overcome by gaining an understanding of the designer's intent and the operator's desired functionality. These two areas are mainly concerned with system performance rather than compliance with any particular prescriptive requirements that may in fact, not be relevant to that particular design (Rattenbury and Fort, 2006).

\section{FUEL CELL TYPES USED IN THE MARINE FIELD}

Fuel cells are referred to by the type of electrolyte used within the system. Currently there are five main types of cells being developed/produced in the stationary fuel cell market. These are the phosphoric acid fuel cell (PAFC), the protonexchange membrane fuel cell (PEM), the molten carbonate fuel cell (MCFC), solid-oxide ceramic fuel cell (SOFC), and the alkaline fuel cell (AFC). In principle, all the fuel cell types listed in Table 1 are suitable for the production of electric energy and for propulsion systems on surface ships. The fuels used by these fuel cells are hydrogen, gases with a high hydrogen content such as methane or liquid hydrocarbons e.g., methanol, diesel fuel., which have to be suitably reformed for use in fuel cell systems. Pure oxygen or air may be used as an oxidizing agent (Sattler, 2000; Leo et al. 2010).

Table 1 Fuel cell types used for surface ships.

\begin{tabular}{|c|c|c|c|}
\hline Fuel cell type & Reactants & Operating temperature $\left({ }^{\circ} \mathrm{C}\right)$ & Efficiency $(\%)$ \\
\hline PEMFC & Air $/$ reformate $\left(\mathrm{H}_{2}\right)$ & 80 & $39-52$ \\
\hline PAFC & Air $/$ reformate $\left(\mathrm{H}_{2}\right)$ & 300 & $38-42$ \\
\hline MCFC & Air / methane & 650 & $40-55$ \\
\hline SOFC & Air / methane & 900 & $45-60$ \\
\hline
\end{tabular}

Among the currently available fuel cell technologies, MCFC and PEMFC are considered as the most promising options for marine applications as they are available in market size, most of materials used in their manufacturing are 
available, and the development of their efficiency is high. In addition, SOFC has in theory the highest potential, but is currently not developed far enough. MCFCs operate at a high operating temperature $\left(650^{\circ} \mathrm{C}\right)$ with a high tolerance to air contamination and carbon monoxide, a contaminant found in the fuel. However, it is sensitive to sulphur or sulphur compounds in hydrocarbon fuels (Alkaner and Zhou, 2006).

MCFC Start-up process is longer than that for the PEMFC. It will take a several hours to warm up the system to more than $600^{\circ} \mathrm{C}$ prior to electrical load acceptance compared to minutes for the PEMCF (Woud and Stapersma, 2003).

\section{FUEL CELL AND ALTERNATIVE MARINE POWER TECHNOLOGIES}

The main challenges of applying fuel cells in the marine environment are to satisfy the requirement of high power density related to weight and size, tolerance to salt air, shock resistance, quick start and load responding characteristics. Apart from the technical performance of fuel cells, capability of using commercially available fossil fuel with low sulfur content, instead of pure hydrogen, is another challenge of fuel cells' application on commercial ships. It has been anticipated that, due to the low volumetric energy density of hydrogen, its use in fuelling fuel cells in commercial shipping will be limited to inland waterways and coastal waters in the future.

Table 2 summarizes a number of key criteria upon which the choice of preferred power technology will be based in the future. These criteria represent characteristics of MCFC and PEMFC candidates. It compares these characteristics with diesel and gas turbine technologies, the two prime competing propulsion candidates. As the technologies mature and experience is gained, specific values may change; however, the key criteria will remain important (Sattler, 2000; El-Gohary and El-Sherif, 2006).

Table 2 Comparison of Alternative Marine Power Technologies (Alkaner and Zhou, 2006; EG\&G Technical Services, 2004).

\begin{tabular}{|c|c|c|c|c|}
\hline Criterion & MCFC & PEM & Diesel & Gas Turbine \\
\hline $\begin{array}{c}\text { Efficiency over a wide } \\
\text { range of loads }\end{array}$ & Relatively flat & Relatively flat & $\begin{array}{c}\text { Best at }>75 \% \text {, poor at } \\
\text { partial load }\end{array}$ & $\begin{array}{c}\text { Best at }>80 \% \text {, very } \\
\text { poor at partial load }\end{array}$ \\
\hline $\begin{array}{c}\text { Response to load } \\
\text { changes }\end{array}$ & Slow at start-up & $\begin{array}{c}\text { Fuel/reformer } \\
\text { dominated }\end{array}$ & Good & Fast \\
\hline Life & 5 years (goal) & 5 years(goal) & years \\
\hline Noise, vibration & Low & Low & High & Medium \\
\hline Power range & $\begin{array}{c}500-2500 k W, \\
\text { modular }\end{array}$ & $\begin{array}{c}20-2500 \mathrm{~kW}, \\
\text { modular }\end{array}$ & Up to $68 \mathrm{MW}$ & Up to $50 \mathrm{MW}$ \\
\hline $\begin{array}{c}\mathrm{NO}_{\mathrm{x}}, \mathrm{CO}, \mathrm{HC} \\
\text { emissions, } \mathrm{CO}_{2}\end{array}$ & $\begin{array}{c}\text { Very low, reduced } \\
\mathrm{CO}\end{array}$ & $\begin{array}{c}\text { Very low, reduced } \\
\mathrm{CO}\end{array}$ & Medium & $\begin{array}{c}\text { Medium, no } \mathrm{CO}_{2} \\
\text { benefit }\end{array}$ \\
\hline
\end{tabular}

\section{KWE PEM FUEL CELL MODEL}

As mentioned before PEMFC and MCFC are considered as the most promising options for marine applications. For the near future, fuel cell can replace the diesel generator, so the selected PEMFC has an advantage over MCFC as their start up time is short. The $250 \mathrm{~kW}$ PEM FCPP model parameters are based on a $440 \mathrm{~V}$ DC bus voltage with a stack current capacity of $94 \mathrm{~A}$, and a cell voltage of $0.72 \mathrm{~V}$.

Based on the above figures, the PEM FCPP consists of six parallel stacks; each stack has 550 cells in series. Using the indicated number of cells and stacks the $250 \mathrm{~kW}$ PEM FCPP, diesel generator, and micro gas turbine model parameters are given in Tables 3 and 4 (Uzunoglu et al., 2007).

The present mathematical model for PEM fuel cell looks at how engineers can model PEM fuel cells to get optimal results for any application. The model was developed to improve fundamental understanding of transport phenomena in PEM fuel cells and to investigate the impact of various operation parameters on performance.

Table $3250 \mathrm{~kW}$ PEM FCPP model parameters.

\begin{tabular}{|c|c|}
\hline Parameter & Value \\
\hline Stack temperature & $343^{\circ} \mathrm{K}\left(70^{\circ} \mathrm{C}\right)$ \\
\hline Faraday's constant $(F)$ & $96,484,600 \mathrm{Ckmol}^{-1}$ \\
\hline No load cell voltage $\left(E_{o}\right)$ & $1.0 \mathrm{~V}$ \\
\hline Number of cells per stack $\left(N_{o}\right)$ & 550 \\
\hline Number of stacks $\left(N_{\text {stack }}\right)$ & 6 \\
\hline Kr constant $=N_{o} /(4 F)$ & $1.4251 \times 10^{-6}{\mathrm{kmol}(\mathrm{s} \mathrm{A})^{-1}}^{0.88}$ \\
\hline Utilization factor $(U)$ & 0.88 \\
\hline
\end{tabular}


Table 4 Diesel generator and micro gas turbine models.

\begin{tabular}{|c|c|c|}
\hline Parameter & $\begin{array}{c}250 \mathrm{~kW} \text { diesel } \\
\text { generator }\end{array}$ & $\begin{array}{c}250 \mathrm{~kW} \text { micro } \\
\text { gas turbine }\end{array}$ \\
\hline Fuel type & Diesel fuel & Diesel fuel \\
\hline $\begin{array}{c}\text { Indicated specific fuel } \\
\text { consumption }(\mathrm{g} / \mathrm{kW} \times \mathrm{hr})\end{array}$ & 220 & 285.7 \\
\hline Speed & $1500 \mathrm{RPM}$ & $3600 \mathrm{RPM}$ \\
\hline
\end{tabular}

Electronically, a fuel cell can be regarded as a serial circuit of an ideal voltage source, $E_{o}$, and a total internal resistance, $R$ as shown in Fig. 1. The higher the current flow, the larger the ohmic voltages drop across the sum of all internal resistances inside the fuel cell. The total ohmic resistance, $T R$, is therefore the combination of the electronic and ionic resistances of various fuel cell components; i.e., ohmic losses occur during transport of electrons and ions (protons) (Hoogers, G. (ed.), 2003).

The PEM fuel cell has been modeled with MATLAB Simulink. The Simulink model developed is a hierarchal model. The top-level block is the block at the top of the hierarchy. This consists of sub-blocks and sub-sub-blocks. The top-level block is analogous to the front end in software programming such as the Control Panel in Lab-View program. The input parameters to the Simulink model are defined and modified in this block. This block consists of die sources and displays of the fuel cell model. The sources to the model are constant value blocks, values of which are predefined. Some of the sources include variable blocks that vary as a function of time.

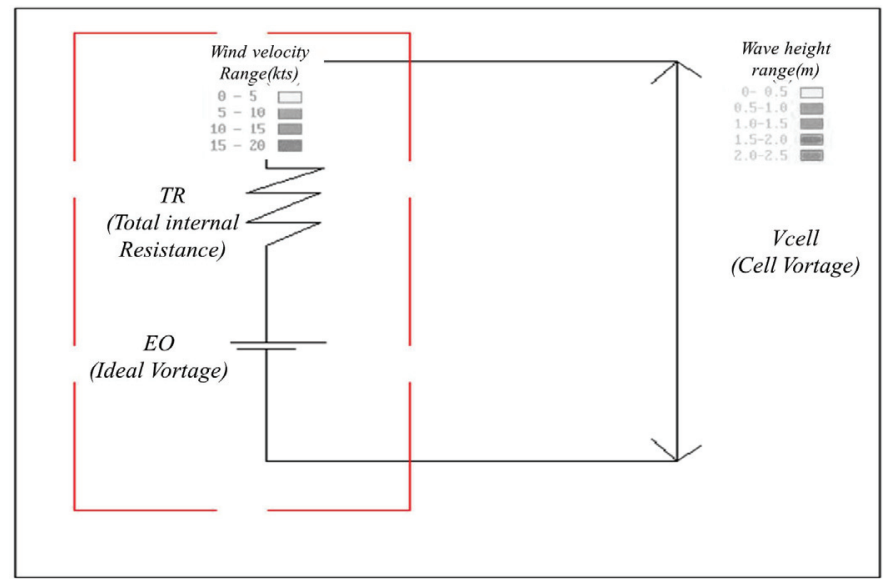

Fig. 1 A simple fuel cell simulator.

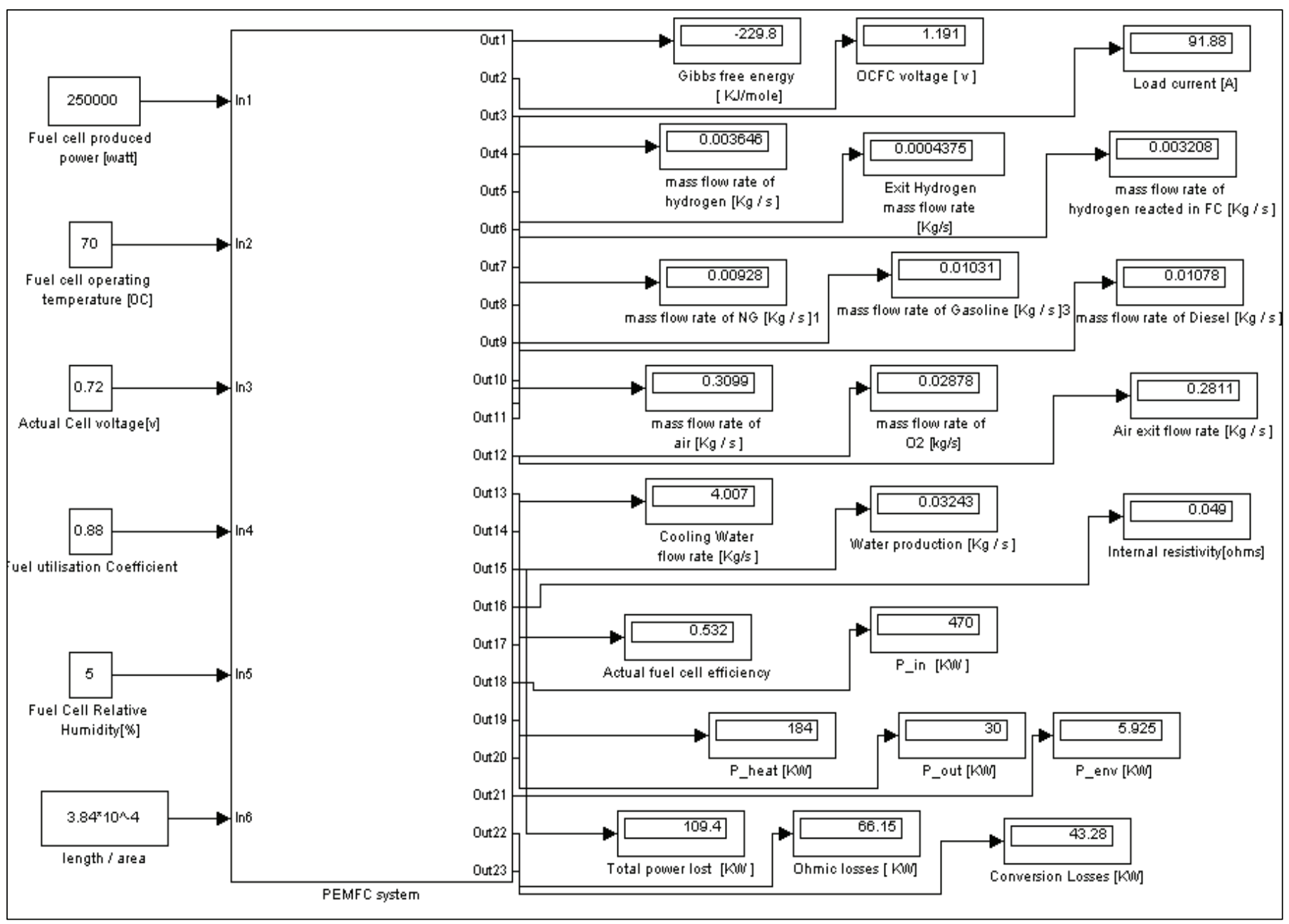

Fig. 2 Simulink top level block. 
Fig. 2 shows the top-level block. The values of input parameters are varied through these blocks. The input data to the model includes relative humidity in the cell, fuel cell output power, fuel cell operating temperature, fuel cell actual voltage, and cell length area ratio. The units of these parameters are shown in the braces following each parameter. Fuel cell efficiency, open circuit voltage, required hydrogen, air, oxygen, diesel, gasoline, and natural gas mass flow rates, and fuel cell power balance are the outputs of the Simulink model

The input data to the model includes relative humidity in the cell, fuel cell output power, fuel cell operating temperature, fuel cell actual voltage, and cell length area ratio. The units of these parameters are shown in the braces following each parameter. Fuel cell efficiency, open circuit voltage, required hydrogen, air, oxygen, diesel, gasoline, and natural gas mass flow rates, and fuel cell power balance are the outputs of the Simulink model

\section{Fuel cell operational voltage}

Fuel cell voltage $\left(V_{\text {cell }}\right)$ is the difference between the cell voltage at no load that can be called as open circuit voltage and specific fuel cell irreversibility or voltage drop. The following equation (1) shows the operating voltage of a fuel cell at a current density $\mathrm{i}_{\text {den }}$ (Larminie and Dicks, 2003; Maroju, 2002).

$V_{\text {cell }}=E_{o}-\left(i_{\text {den }} \times r\right)-A \times \ln \left(i_{\text {den }}\right)+m \exp \left(n \times i_{\text {den }}\right)$

In this equation, $E_{o}$ is the open circuit voltage, ' $i_{n}{ }^{\prime}$ internal current density, ' $A$ ' is slope of Tafel curve, ' $m$ ' and ' $n$ ' are constants, ' $r$ ' is specific resistance. Typical values of these constants for a PEM fuel cell are given in Table 5.

Table 5 Typical values of over voltage parameters (Larminie and Dicks, 2003).

\begin{tabular}{|c|c|}
\hline Constant & Typical Value \\
\hline$E_{o}$ & $1.031 \mathrm{~V}$ \\
\hline$r$ & $2.45 \times 10^{-4} \mathrm{k} \Omega \mathrm{cm}^{2}$ \\
\hline$A$ & $0.03 \mathrm{~V}$ \\
\hline$m$ & $2.11 \times 10^{-5} \mathrm{~V}$ \\
\hline$n$ & $8 \times 10^{-3} \mathrm{~cm}^{2} \mathrm{~mA}^{-1}$ \\
\hline
\end{tabular}

\section{Fuel cell polarization curve}

The present study assumes $88 \%$ utilization of hydrogen in the cells. The inlet air to the cathode is humidified to a relative humidity of $30 \%$. The anode inlet stream is also humidified if necessary. The fuel cell stack is assumed to run under constant temperature and pressure, namely $70^{\circ} \mathrm{C}$ and 3bars. The fuel cell polarization curve, Fig. 3, shows the relation between cell output voltage and current density at different specific cell resistance. The higher the current density had drawn from the fuel cell, the lower the output voltage from the fuel cell.

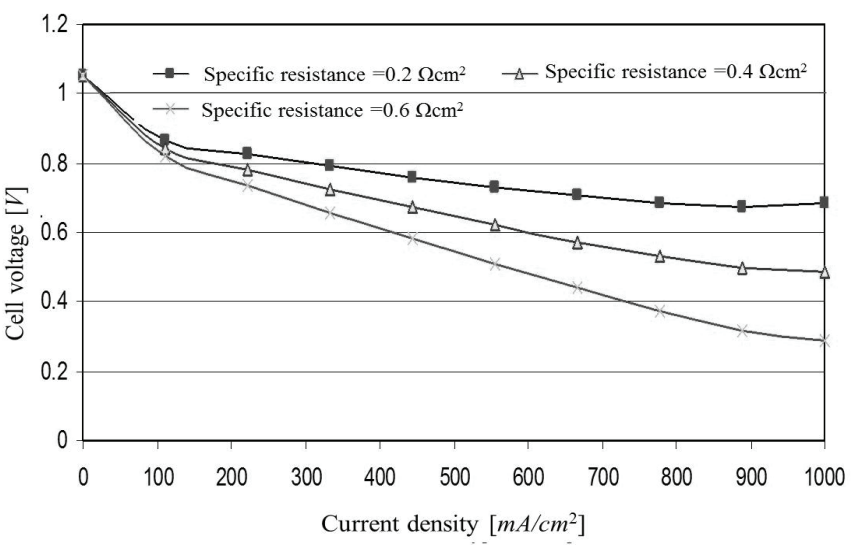

Fig. 3 Fuel cell voltage at different specific resistance.

\section{Required air, hydrogen, and oxygen flow rates for the model}

The required mass flow rates of hydrogen, oxygen, and air in $\mathrm{kg} / \mathrm{s}$ are expressed in Eqs. (2, 3, and 4) respectively, and the value of utilization factor $U_{f}$ in Eq. (5) refers to the ratio of hydrogen reacted in the fuel cell (Holland and Zhu, 2007; Kumm, 1990). Exit air flow rate can be calculated by the difference between inlet air flow rate and oxygen usage.

The required hydrogen mass flow rate can be written as:

$m_{H 2}=\frac{1.05 \times P_{\text {el }}}{10^{8} \times V_{\text {cell }}}$

The required oxygen mass flow rate can be written as:

$m_{\mathrm{O}_{2}}=\frac{8.29 \times P_{\text {el }}}{10^{8} \times V_{\text {cell }}}$

The required air mass flow rate can be written as:

$m_{\text {air }}=\frac{3.57 \times \lambda_{\text {air }} \times P_{e l}}{10^{7} \times V_{\text {cell }}}$

In addition, the hydrogen mass flow rate reacted in fuel cell can be written as:

$m_{H 2 \text { cons }}=m_{H 2} \times U_{f}$

Hydrogen formula in Eq. (1) only applies to a hydrogenfed fuel cell. In the case of a hydrogen/carbon monoxide mixture derived from a reformed hydrocarbon, it will be different; Eq. (6) shows the relationship between the efficiency of the fuel cell, the heating value "CV in $\mathrm{kJ} / \mathrm{kg}$ " of the fuel and the resulting fuel rate in $\mathrm{kg} / \mathrm{s}$ (Sjöstedt and Chen, 2009).

Fuel flow rate $=\frac{P_{e l}}{\eta_{F C} \times C V_{\text {fuel }}}$ 
Fuel cell cooling supply incorporates both air-cooling and water-cooling. The air-cooling is forced convection cooling while the water-cooling involves the flow of distilled water through the cooling channels of the PEM fuel cell stack. The mass flow rate of the coolant water in $\mathrm{kg} / \mathrm{s}$ is calculated using Eq. (7) (Holland and Zhu, 2007; Kumm, 1990).

$$
m_{\text {coolingwater }}=\frac{1.025 \times P_{\text {el }} \times\left(1.25-V_{\text {cell }}\right)}{V_{\text {cell }} \times C_{p} \times \Delta T}
$$

\section{RESULTS AND DISCUSSION}

The output current density from fuel cell expressed in $\mathrm{mA} / \mathrm{cm}^{2}$ depends on hydrogen mass flow rate and number of cells as can be shown in Eq. (8). Also, the output power density expressed in $\mathrm{kW} / \mathrm{cm}^{2}$ depends on the number of cells, output current density, and cell voltage as can be shown in Eq. (9) (Ersoz et al., 2005).

$$
\begin{gathered}
i_{\text {den }}=\frac{m_{H 2} \times 10^{11}}{1.04 \times n_{\text {cell }} \times A_{\text {active }}} \\
P_{\text {eld }}=\frac{V_{\text {cell }} \times i_{\text {den }} \times n_{\text {cell }}}{10^{6}}
\end{gathered}
$$

The number of cells in the fuel cell stack is one of the key parameters, which affects the fuel cell output power and hence electrical efficiency as illustrated in Fig. 4. The ratio between calculated current and load current density is called the active area for the fuel cell stack as can be shown in Eq. (10). So, the required area for fuel cell stack changes with stack cells as shown in Fig. 5. In this study, the number of cells has been changed between 2000 and 4000 .

$A_{\text {active }}=\frac{i_{\text {cal }}}{i_{\text {den }}}$

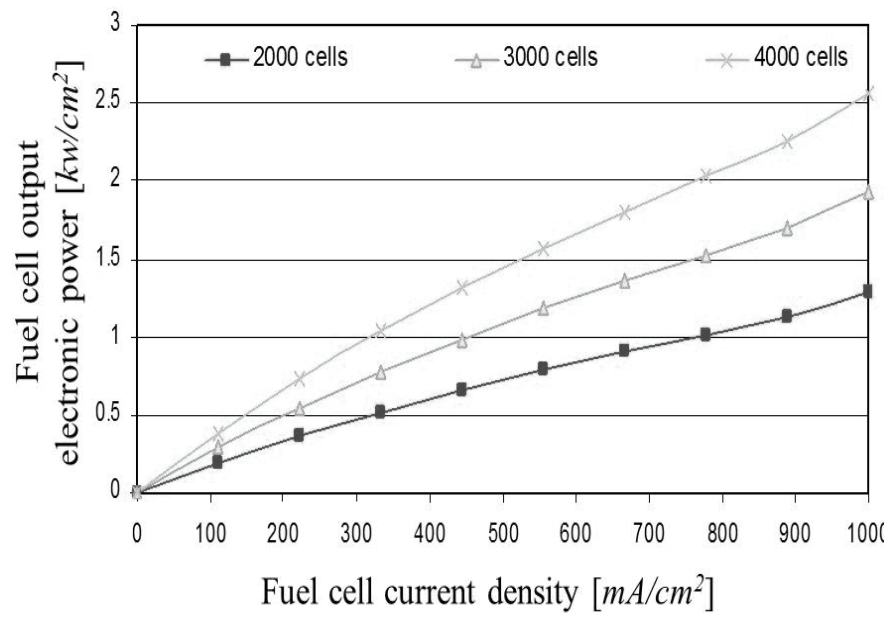

Fig. 4 Fuel cell output power for different number of cells.

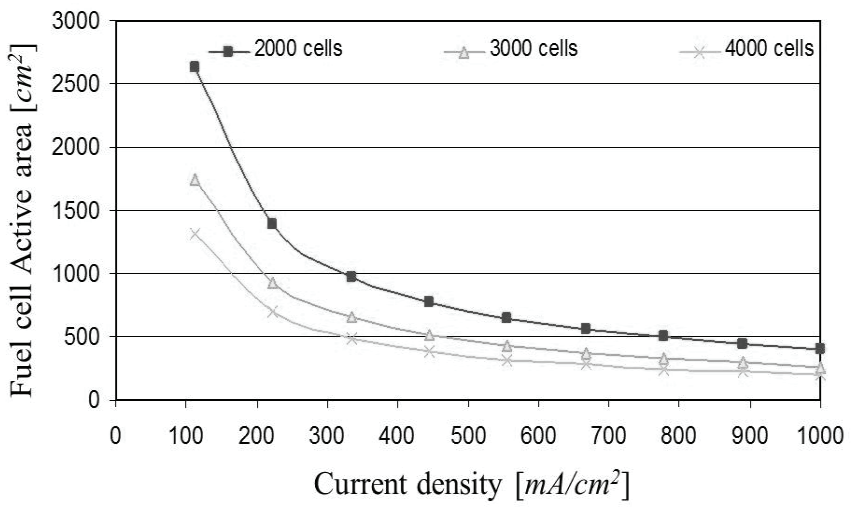

Fig. 5 Fuel cell active area at different number of cells.

The number of cells in fuel cell stack plays an important role in determining the output characteristics of the fuel cell like the current density output and the power density output from the fuel cell stack as can be shown in Fig. 6. As the number of cells increases the current density decreases at different fuel cell available areas. At the same current density, there are ranges of available number of cells at different fuel cell active areas.

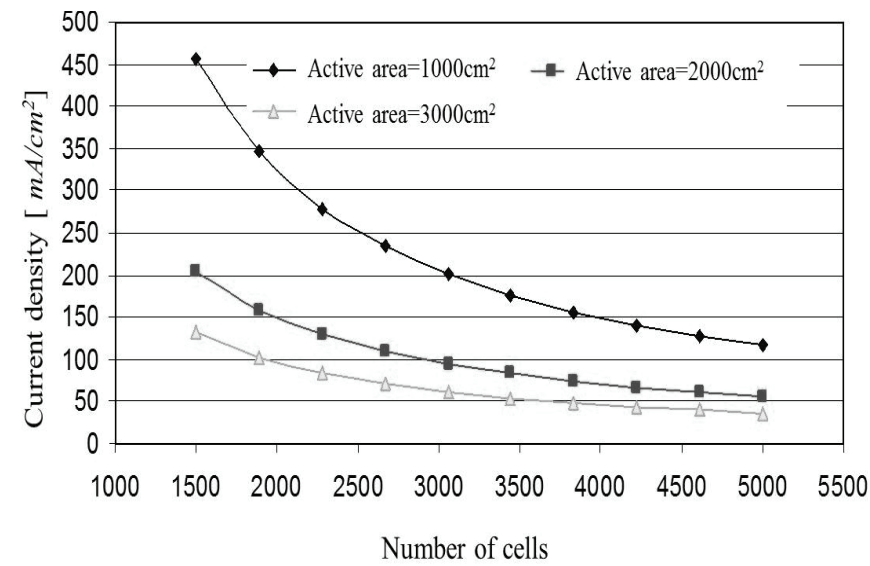

Fig. 6 Fuel cell current density at different number of cells.

\section{Fuel cell efficiency calculations}

If all the energy from the hydrogen fuel, its 'calorific value', heating value, or enthalpy of formation, were transformed into electrical energy, then the EMF would be given by (Larminie and Dicks, 2003):

$$
E_{o}=\frac{-\Delta h_{f}}{2 F}
$$

So, the efficiency of fuel cell can be expressed as

$\eta_{F C}=U_{f} \frac{V_{\text {cell }}}{E_{o}}$ 
Where, $U_{f}$ is fuel utilization coefficient. A good estimate for $U_{f}$ is 0.95 , which allows the efficiency of a fuel cell to be accurately estimated from the very simple measurement of its voltage.

Efficiency limit for heat engines such as steam and gas turbines can be calculated using Carnot efficiency limit which shows their maximum efficiency, but fuel cells are not subject to the Carnot efficiency limit. It is commonly supposed that if there were no 'irreversibilities' then the efficiency could be $100 \%$. Fig. 7 shows Carnot efficiency for heat engines and fuel cell efficiency limit. Fuel cell efficiency limit is greater than that of Carnot efficiency for the operating temperatures from $100^{\circ} \mathrm{C}$ to $750^{\circ} \mathrm{C}$. When the operating temperature reaches $750^{\circ} \mathrm{C}$, the Carnot efficiency equals that of fuel cell efficiency limit. As the operating temperature increases above $750^{\circ} \mathrm{C}$, the heat engines will have a Carnot limit higher than that of fuel cell efficiency limit.

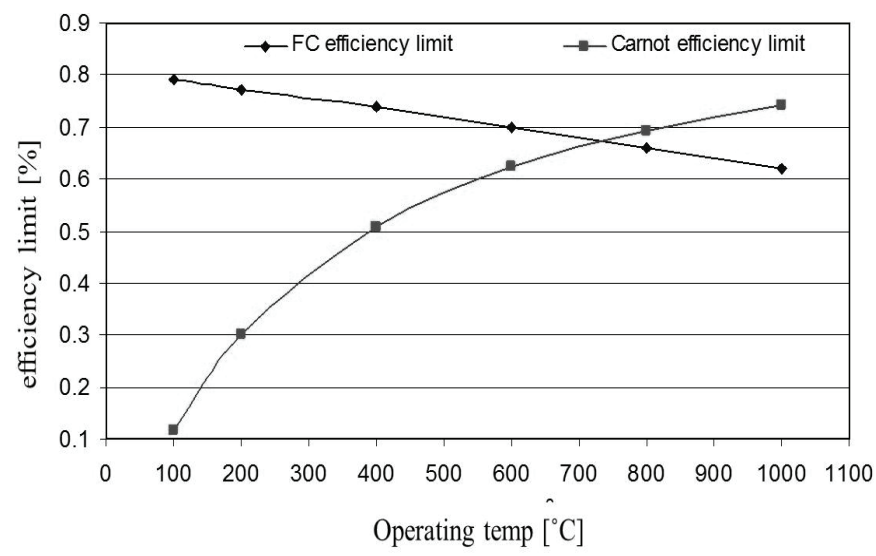

Fig. 7 Efficiency limit for fuel cell and heat engines.

Fuel cell Efficiency affects the required mass flow rates of hydrogen, natural gas, gasoline, and diesel fuels. Fuel utilization coefficient determines the amount of hydrogen consumption in fuel cell and also affects the cell efficiency as shown in Fig. 8.

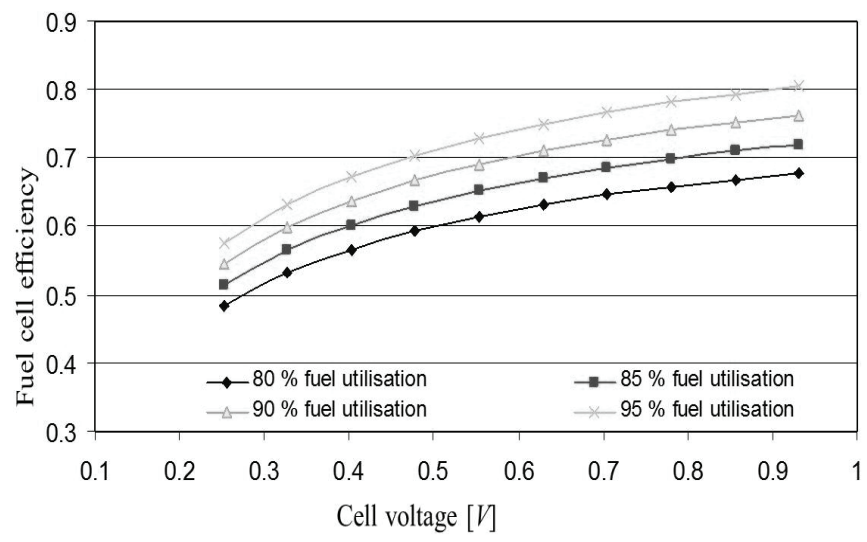

Fig. 8 Fuel cell efficiency at different fuel utilization factors.

The higher the fuel utilization coefficient for fuel cell, the higher fuel cell efficiency will be obtained. Every fuel cell has a utilization coefficient which corresponds to the output cell voltage. At constant cell voltage, the hydrogen consumption will be decreased as the fuel utilization coefficient increases. When the fuel cell voltage increases the required hydrogen flow rate will be decreased for the same output power. For the selected case study the cell voltage is 0.72 volt. So the fuel cell efficiency will range between $40 \%$ and $55 \%$ at different fuel utilization coefficients. For $88 \%$ fuel utilization coefficient, the fuel cell efficiency is $53.53 \%$. The hydrogen consumption is $13.04 \mathrm{~kg} / \mathrm{hr}$ for the $250 \mathrm{kWe}$ PEMFC at 0.72 cell voltage

\section{Fuel cell and other marine alternatives power balance}

The polarization curve defines the cell voltage, which can be used in power calculation for fuel cell. The power in inlet streams to the fuel cell should be equal to the output electric power in addition to the other losses as can be expressed in the following equation (13):

$P_{\text {in }}=P_{\text {el }}+P_{\text {heat }}+P_{\text {out }}+P_{\text {env }}$

Fuel cell power balance based on pure hydrogen produced from water electrolyze which can be compared with heat balance for other power alternatives, micro gas turbine and diesel generator which operate with diesel fuel.

Fuel cells are efficient in part load application. So, they have the ability to maintain efficiency through a range of loads, at loads between 30 to 100 percent of rated output. Conventional systems, on the other hand, are less efficient at the lower end of this range as shown in Fig. 9.

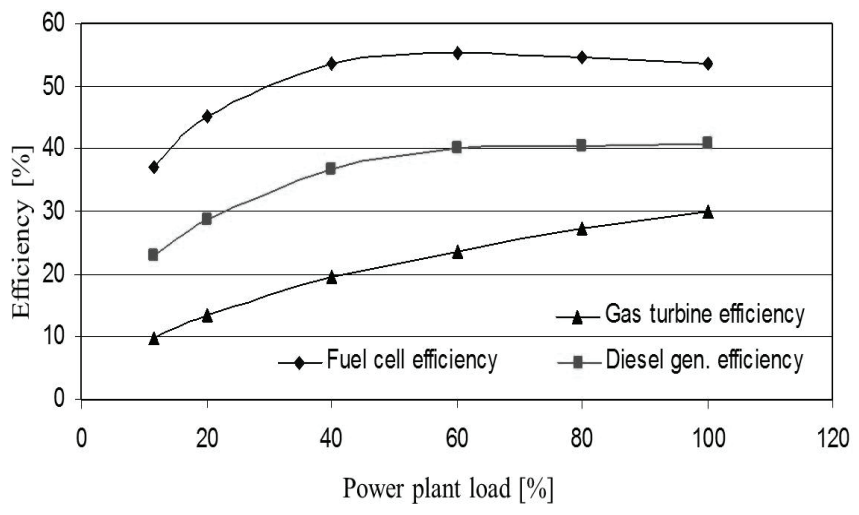

Fig. 9 Ship Service Fuel Cell (SSFC) efficiency compared to different power plants.

Fig. 10 shows fuel energy consumption for different power alternatives at different working loads. Fuel cell system achieves best efficiency and minimum fuel energy consumption compared with micro gas turbine and diesel generator (Woodyard, 2004, and U. S. National Technical Information Service, 1999). As shown in Fig. 10, the 250$k W e$ fuel cell fuel energy consumption will be lower than that of equivalent 250-kWe diesel generator and micro gas turbine. The micro gas turbine shows the highest fuel consumption at different working loads. At the full load, the values of fuel energy consumption decrease for diesel generator, and micro gas turbine than that at part loads. For $250-\mathrm{kWe}$ power output the fuel energy consumption at full load for micro gas turbine, 
diesel generator, and fuel cell is 833.3, 611.2, and $467 \mathrm{~kW}$ respectively.

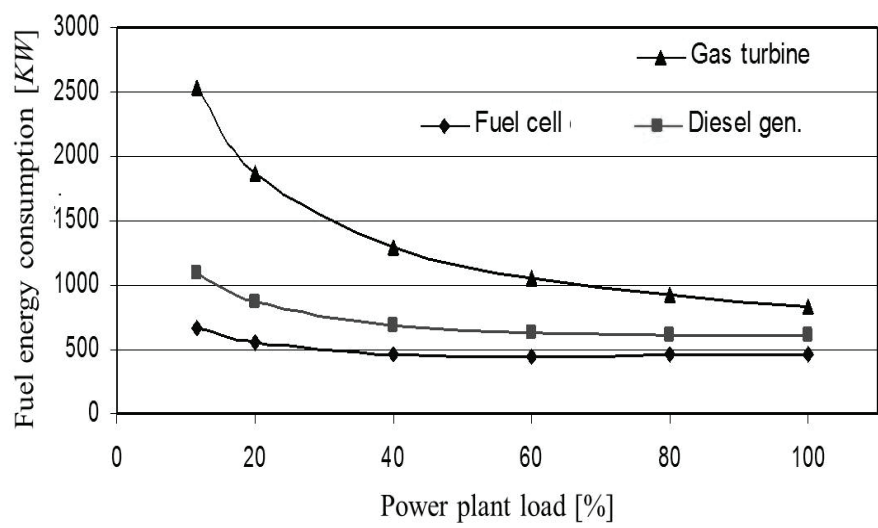

Fig. $10250-k W e$ fuel energy consumption for different power alternatives.

The power lost in heat is shown in Fig. 11. From the heat and power balance of the $250 \mathrm{kWe}$ different power alternatives the heat losses are $181.3 \mathrm{~kW}, 342.8 \mathrm{~kW}$, and $558.3 \mathrm{~kW}$ with percentages of $38.8 \%, 56 \%$, and $66.99 \%$ for fuel cell, diesel generator, and micro gas turbine respectively. The diesel generator heat losses include both cooling water heat losses and exhaust gases losses.

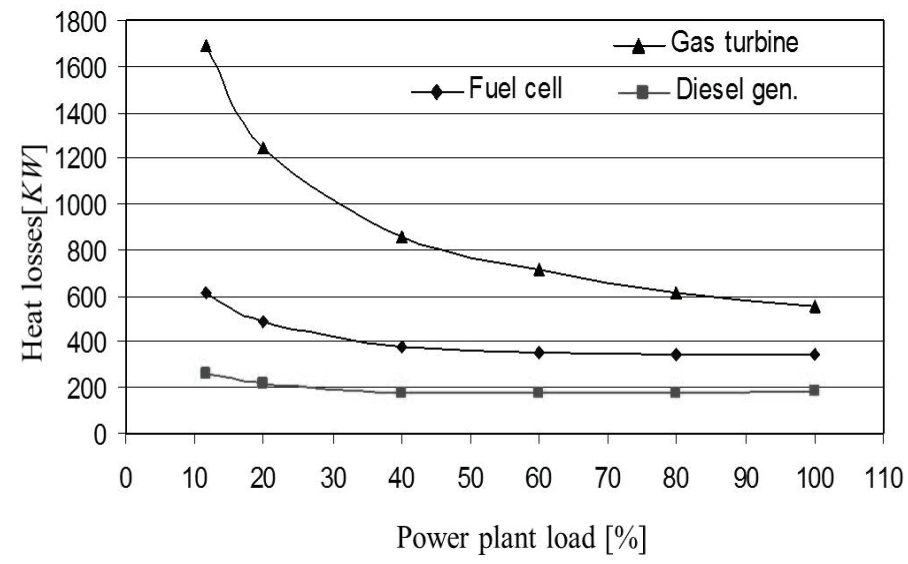

Fig. 11 250-kWe heat loss from different power alternatives.

In a hydrogen-fed fuel cell, water is produced at the rate of one mole for every two electrons. So, fuel cell water produced mass flow rate in $\mathrm{kg} / \mathrm{s}$ can be calculated using Eq. (14).

$m_{\text {water }}=\frac{9.34 \times P_{e l}}{10^{8} \times V_{\text {cell }}}$

For a proton exchange membrane fuel cell (PEMFC), there must be sufficient water content in the polymer electrolyte. The proton conductivity is directly proportional to the water content. However, there must not be so much water to the extent that the electrodes which are bonded to the electrolyte, flood, blocking the pores in the electrodes or the gas diffusion layer. A balance is therefore needed for the water content.

The water production from fuel cell and the water drag are both directly proportional to the current. The back diffusion of water from cathode to anode depends on the thickness of the electrolyte membrane and the relative humidity of each side. Finally, if external humidification of the reactant gases is used prior to entry into the fuel cell, the process can be controlled. For the $250 \mathrm{kWe}$ PEMFC, the water production will be at a rate of $116 \mathrm{~kg} / \mathrm{hr}$ at the cell voltage of 0.72 volt. Water production flow rate from fuel cell depends on the output power from the fuel cell, the water production increases with the increase of output power as shown in Fig. 12.

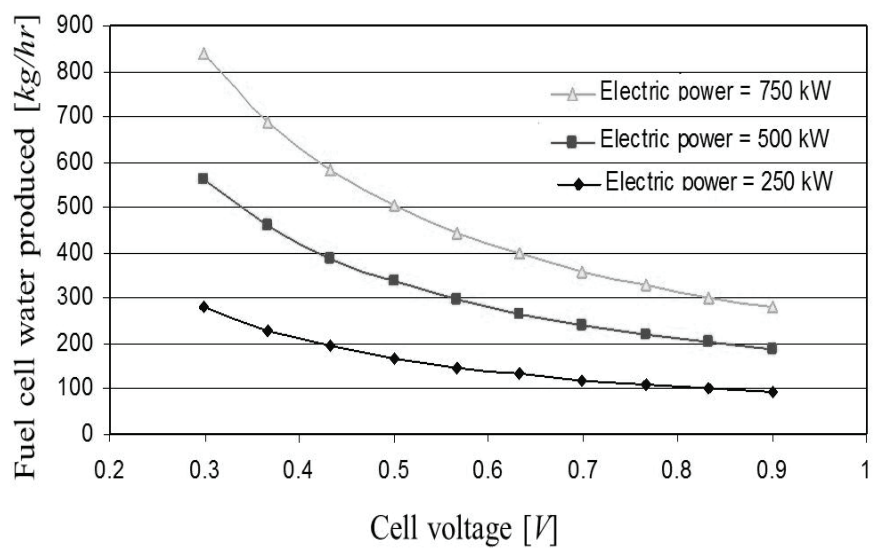

Fig. 12 Produced water flow rates from fuel cell at different electric powers.

\section{CONCLUSIONS}

Efficient and zero emission ships are of utmost importance for the future in terms of sustainable development. Fuel cell systems are considered for powering future ships in an efficient and low emitting manner, as they are environmentally friendly source of energy due to their superefficient use of fuel for electricity and heat. The electrical energy conversion efficiency of most fuel cells ranges between $40 \%$ and $60 \%$ based on the lower heating value (LHV) of the fuel. Among the currently available fuel cell technologies, MCFC, SOFC, and PEMFC are considered as the most promising options for marine applications. Within this frame the low temperature proton exchange membrane (PEM) fuel cell systems are being developed globally.

The parameters, which affect fuel cell performance, include the number of cells, cell voltage, open cell voltage, fuel cell efficiency, and fuel utilization coefficient. The actual PEM cell voltage is 0.868 volt and the open cell voltage is 1.031 volt. These two values affect the efficiency and performance of the fuel cell. Also, fuel utilization coefficient determines the amount of hydrogen consumption in fuel cell and also affects the cell efficiency. 
The proposed mathematical model of a $250 \mathrm{kWe}$ power balance systems shows that the percentage of power lost in heating for fuel cell power plant is much less than that of diesel generator and micro gas turbine. Using diesel generator, micro gas turbine will increase the fuel energy consumption rate by $23.59 \%, 43.95 \%$ more than that of fuel cell fuel energy consumption at full load for the same output power $250 \mathrm{kWe}$.

\section{REFERENCES}

Alkaner, S. Zhou, P. 2006. A Comparative Study on Life Cycle Analysis of Molten Carbon Fuel Cells and Diesel Engines for Marine Application. Journal of power sources, 158 , pp. 188-199.

EG\&G Technical Services, 2004. Fuel Cell Handbook. Seventh Edition, National Technical Information Service, U.S. Department of Commerce, pp. 10-15.

El-Gohary, M.M., 2007. Design of Hydrogen Marine Gas Turbine. Alexandria Engineering Journal, 45, pp.42-53.

El-Gohary, M.M., 2008 Design of Marine Hydrogen Internal Combustion Engine. Alexandria Engineering Journal, 47(1), pp.57-65.

El-Gohary, M.M. Naguib, A. and Ammar, N.R., 2008. Evaluation of Applying Fuel Cell Technology in Nile Floating Hotels. $7^{\text {th }}$ International Conference on Role of Engineering Towards a Better Environment, 7, pp.20-33.

El-Gohary, M.M. and El-Sherif, H.A., 2006. Future of Hydrogen as Green Energy in Marine Applications. 9th World Renewable Energy Congress, Florence, Italy, pp. 229-237.

Ersoz, A. Olgun, H. and Ozdogan, S., 2005. Reforming Options for Hydrogen Production from Fossil Fuels for PEM Fuel Cells. Journal of Power Sources, 154, pp. 67-73.

Hoogers, G. (ed.), 2003. Fuel Cell Technology Hand Book. London New York Washington: CRC Press. 0-84930877-1, pp. 8-30.

Holland, B.J. and Zhu, J.G. 2007. Design of A 500 W PEM Fuel Cell Test System. Faculty of Engineering, University of Technology, Sydney, Broadway, NSW, pp.1-6.
Hordeski, M.F., 2008. Alternative Fuels-The Future of Hydrogen. 2nd Ed. India: Fairmont Press. ISBN 088173-596-5, pp. 175-180.

Woud, H.K. and Stapersma, D., 2003. Design of propulsion and electric power generation systems. Institute of Marine Engineers (IMarEST), London, England, ISBN 978-1902536477, pp. 20-35.

Ritch, E. and Cleantech Group, 2008. Focus: Proton Motor debuts first fuel cell passenger ship. [online] 29 August. Available at:http://cleantech.com/news/3334/ protondebuts-fuel-cells-run-german-ship

Kumm, W.H., 1990. Marine and Naval Applications of Fuel Cells for Propulsion: The Process Selection. Journal of Power Sources, 29, pp. 169-179.

Leo, T.J. Durango, J.A. and Navarro, E., 2010. Exergy Analysis of PEM Fuel Cells for Marine Applications. Journal of Energy, 35, pp.1164-1171.

Larminie, J. and Dicks, A., 2003. Fuel Cell Systems Explained. $2^{\text {nd }}$ Edition, England: John Wiley \& Sons Ltd., ISBN 0-470-84857-X, pp. 45-66.

Maroju, P., 2002. Modeling of a Fuel Cell. Master of Science Thesis, Texas Tech University,USA, p. 36.

Rattenbury, N. and Fort, E., 2006. Development of Requirements for Fuel Cells in the Marine Environment Performance and Prescription. Lloyd's Register Technical Papers, London, England, pp. 3-20.

Sattler, G., 2000. Fuel Cells Going on-Board. Journal of power sources, 86, pp. 61-67.

Sjöstedt, C.J. and Chen, D.J., 2009. Virtual Component Testing for PEM Fuel Cell Systems: An Efficient, HighQuality and Safe Approach for Suppliers and OEM's. $3^{\text {rd }}$ European PEFC Forum, Session B09, pp.25-30.

U.S. National Technical Information Service., 1999. Marine Fuel Cell Market Analysis. Final Report No. CG-D-1900 , pp.15-25.

Uzunoglu, M. Onar, O. El-Sharkh, M.Y., Sisworahardjo, N.S. and Rahman, A., 2007. Parallel operation characteristics of PEM fuel cell and microturbine power plants. Journal of Power Sources, 168, pp. 469-476.

Woodyard, D. (ed.), 2004. Pounder's Marine Diesel Engines. 8th edition, Butterworth-Heinemann: Elsevier Ltd., London, ISBN 075065846 0, pp. 49-55. 